\title{
Structural Value Of Empyak
}

\author{
A. Robbi Maghzaya ${ }^{1}$, Prihatmaji, Yulianto ${ }^{2}$, Pradipto, Eugenius ${ }^{3}$ \\ ${ }^{1}$ Architecture, Universitas Islam Indonesia, Jl. Kaliurang Km 14.5 Sleman Yogyakarta \\ ${ }^{2}$ Architecture, Universitas Islam Indonesia, Jl. Kaliurang Km 14.5 Sleman Yogyakarta \\ ${ }^{3}$ Architecture, Universitas Gajah Mada, Jl. Grafika 2 Sleman Yogyakarta \\ arobbimaza@gmail.com, prihatmaji@uii.ac.id, epradipto@yahoo.com
}

\begin{abstract}
Empyak is a part of the traditional building that must be developed to preserve its existence. This paper explores the impact of construction method and structural behavior of empyak. The identification of how structurally work is essential as a primary information to develop the construction of empyak. Initially, a model with scale 1:3 was made to understand structural behavior under the seismic simulation. Some observation will be done to find out the changing of its shape under seismic forces. The results of this research are limited to understand the function of every element in the building stability. The result of the study will be useful for the development of traditional architecture. Empyak not only regards as a construction element but also as a structural element, which is the subject of the study.
\end{abstract}

Keywords: Empyak, structure, construction, bamboo

\begin{abstract}
ABSTRAK
Empyak adalah salah satu elemen bangunan tradisional Yogyakarta yang perlu dilestarikan. Artikel ini membahas mengenai konstruksi empyak terhadap perilaku struktur bangunan keseluruhannya. Bagaimana empyak bekerja sebagai elemen struktural perlu dipelajari untuk dikembangkan dengan metode yang lebih modern. Pemahaman mengenai perilaku struktur empyak dilakukan dengan pengamatan model konstruksi dibawak berbagai karakter pembebanan. Observasi terhadap model berfungsi untuk mengetahui perubahan bentuk setelah dilakukan pembebanan. Penelitian ini dibatasi pada fungsi-fungsi struktural setiap elemen empyak untuk mendapatkan bangunan yang stabil. Penelitian ini bermanfaat untuk memahami bagaimana nilai-nilai konstruksi dan struktur yang ada dalam konstruksi empyak.
\end{abstract}

Keywords : Empyak, struktur, konstruksi, bambu

\section{INTRODUCTION}

In south-east Asia, there is many culture variety. Its always become attractive and have a high impression to the visitor or tourism (Waterson, 1998). In term of architecture, we can identify the uniqueness of its construction by the shape of the roof. For example, in Indonesia, almost every province has distinguished form of the roof. Gadang, Karo, Nias, Panjang, Tongkonan, and Honai are the example of houses that have distinctive shape of the roof.

Java island in Indonesia also has a traditional building with a unique shape that reflects the richness of Javanese culture. Traditional architecture in Java, especially in Yogyakarta, like Panggang $\mathrm{Pe}$, Joglo, Limasan, Kampong, and Tajug are distinguished by the shape of the roof (Ismunandar, 2007). Another variation in traditional roof construction is empyak.

Empyak is one of the roof elements in the traditional building construction. Construction empyak mostly is used by people from midlow social level. The usage of Empyak primarily constructed in two type of the roof, which is kampong and limasan houses (see Figure 1).

Empyak, geometrically, has a various kind of shape. It depends on the type of the roof. Kampong house uses the combination of two rectangular empyak. While in the limasan

Tesa Arsitektur Volume 15| Nomor 2 | 2017 
building, we can find the combination of trapezoid and triangle shape (see Figure 2). There are several types of bamboo arrangement in empyak construction. Empyak was a cheap solution that can be reached by mid-low range people to get a house that structurally qualified.

This element is constructed on the ground before attached to the top of the structure. After the panel completed, the worker will lift it manually on the top of the structure frame. So, every part of an empyak element not assembled piece by piece directly on the top of the structure, like conventional way.

The roof is an essential element of the building, so that, its design will be unique (Soeroto, 2003), especially for traditional building in a tropical area like south-east Asia. This uniqueness can be the identity of culture in some place. But, now, there is a challenge in present day to use the old construction methods. The demand of modern culture needs the more efficient way and system which is difficult to achieve by traditional systems. This problem also occurs in the use of traditional construction, such as empyak. Modern people will tend to use new technique or material that much easier to be applied than old construction. In case of Empyak, this shift causing this technology not develop, and gradually abandoned.

Empyak lies on the structure of the building that generally, have similar construction and element. The main structure of Yogyakarta traditional wooden traditional called rongrongan (Frick, 1997). Rong-rongan is frame system that consists of sokoguru, blandar, pengeret. In comparison, there is no triangle truss element as a primary roof support like in conventional roof structure. So the question is how empyak construction can afford its stability from the lateral force?, while its main structure not stable under low-frequency seismic force (Prihatmaji, 2007).

This paper seeks to explore the construction method and structural behavior of empyak to reach building stability. An understanding of both construction and structural aspect can be used to develop the origin technology of the building in Indonesia.

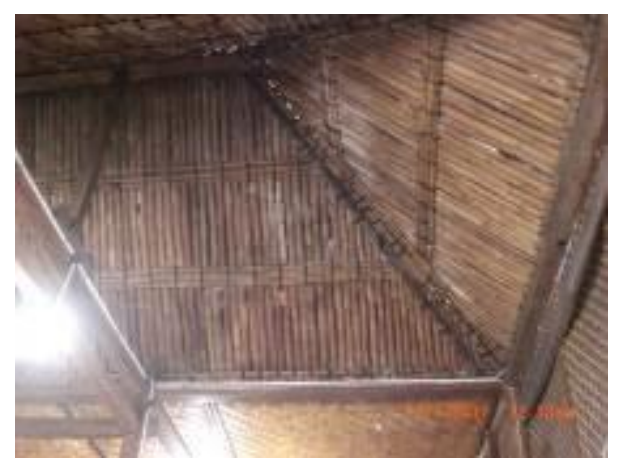

(a)

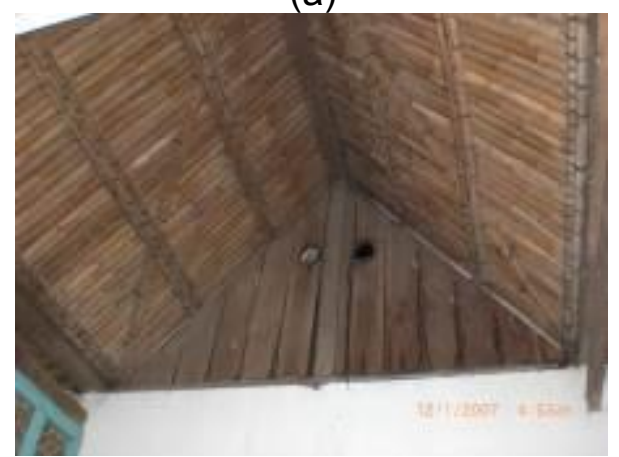

(b)

Figure 1. Empyak construction of limasan roof (a) and kampung roof (b) (Source: author)

METHODOLOGY 
First of all, to understand how the empyak works structurally and constructionally, empyakit needs to identify the original construction. Start with the study of two sample from two different types of traditional houses in Yogyakarta that is kampung house and limasan house. That use empyak for its roofing element. These two buildings represent typologies of empyak basic form.

Some interview with traditional craftsmaster of empyak has been done to know the detail of the construction process. After collecting interview and observation data, this research will build a model of empyak in scale $1: 3$ as a tool for the simulation to study the structural behavior.

This research will observe on the construction stability before its attached to the main structure and observe the structural stability after empyak panel attached to the main structure. The experimental treatment has been done manually to apply tension force, compression force, bending force, torsion force (Cowan, 1971) and shear force (Ravi Malapundi and Ayoub, 2010) on the construction. Every treatment on the model will be observed the changes of its shape and identify the elements that react to the forces.

\section{BASIC THEORY}

The structure must fulfill the requirements of stability in every possible loading condition (Schodek, 1995). So that, to determine whether it has structural value or not, it can be seen from the symptom of the stability of the construction by transmission of the force from one spot to another (Marshall, 1969). As structural element empyak also need to maintain not only the stability of the panel itself but also the stability of the whole systems that work on the building.

Empyak is plane elements of the roof made from bamboo tied into one panel. Empyak composed by several elements, namely gendong, gapit, usuk, reng, and gapit kupu tarung (Hamzuri). Every element tied together with a traditional rope called ijuk. ljuk is made from the part of aren tree (Arenga pinnata). Initially, empyak do not use nails to strengthen the joint. Javanese peoples belief nails are not strong enough to hold all the connections and can damage the material (Frick, 1997).

The important aspect that determines the structure whether strong or weak is construction joints. The joint properties and condition will influence the structure system of the building. The weaker joint can makes the system of the structure fail (Cowan, 1971). The top connections between empyak and the frame of the building use bonding system with a traditional rope called plilit made from bamboo. While in the bottom support is locked with wooden pegs. Pegs and rope serve as an anchor to prevent empyak panel apart from the main structure and lifted by the wind (Crane, 1947).

The wind force on the roof must be considered to achieve stability of the building. Yogyakarta traditional buildings have a relatively tall shape of the roof that will create greater wind force on the roof compared to building with flat roof.

Empyak construction uses bamboo as a material alternative for wood as the main structure of the traditional building in Yogyakarta. Bamboo is more economically feasible material (Ghavami, 2008). It easy to plant, harvest, and treatment. The other advantages of bamboo are easy to construct, resilient to the wind force, resilient to earthquake forces, and easy to repair in the event of damage (Jayanetti, D.L. \& Follett, P.R., 2008).

Traditional roof construction needs into two types, namely stilts roof system and truss system construction (Frick, 2004). Among the two types of roof construction, the truss system is more stable to withstand lateral forces because it has a diagonal formation (Schodek, 1997). While on the stilts roof system, there are elements called ander that need to be combined with other elements as stiffeners. Ander is a vertical beam that sustains molo, mounted perpendicular to the pengeret beam. Ander is only founded in the kampung and limasan houses (Ismunandar, 2007).

\section{RESULT AND DISCUSSION}

\section{Construction of Empyak}

Tesa Arsitektur Volume 15| Nomor 2 | 2017 
Empyak is the composition of bamboo materials combined with ijuk rope. Empyak usually can be found in two types of Yogyakarta traditional houses, which are kampong and limasan. All of the empyak components are made from a different cut of bamboos.

Gendong is made from full round or half round cross section bamboo placed in every 3-4 of usuk. Full shape gendong has several holes, called ngiras gaplok across the rod to allow gapit insert gendong. The placement of gendong always puts the bottom of the rod on the peak of the roof. This because the bottom side of the bamboo is more resistant to water and moisture than the opposite side.

Gapit serves to unite usuk of empyak by flanking. Every panel consists of a pair of 2-3 rod of split bamboo. Gapit on the back side of empyak placed through the gendong hole to obtain uniform clamping on the surface of usuk, as well as preventing the gapit slide down when vibration occurs in empyak.

Usuk is made from bamboo that split into two. So, it has half circle cross-section, and it is arranged parallel with gendong and perpendicular with gapit.

Gapit sidang or gapit kupu tarung are diagonal elements to maintain the stability of the rectangular empyak panel. These features only are found in rectangular empyak. Unlike gapit, gapit sidang is constructed not in a pair but only on the front side of the empyak and tied with usuk.
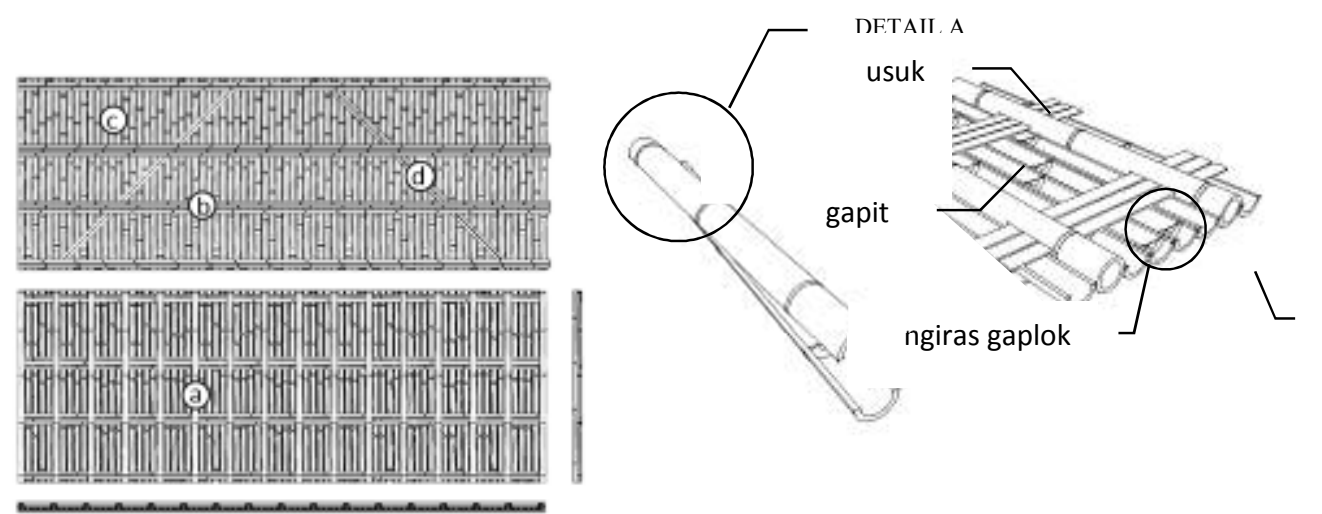

full rounded gendong
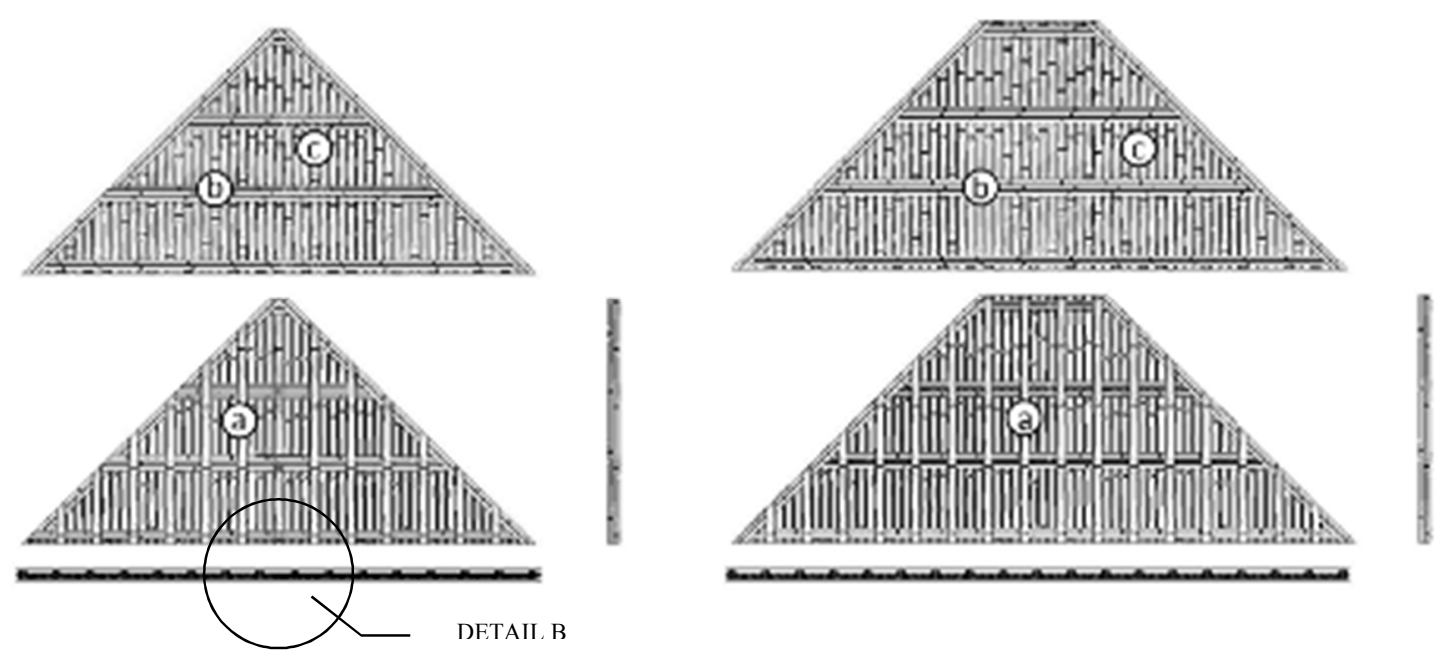


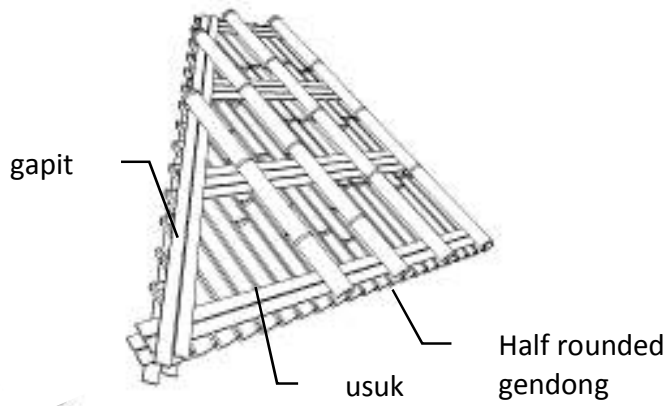

Figure 2. Empyak Panel Assemblies: Gendong (a), Gapit (b), Usuk (c), Gapit Sidang (d). (Source: author)
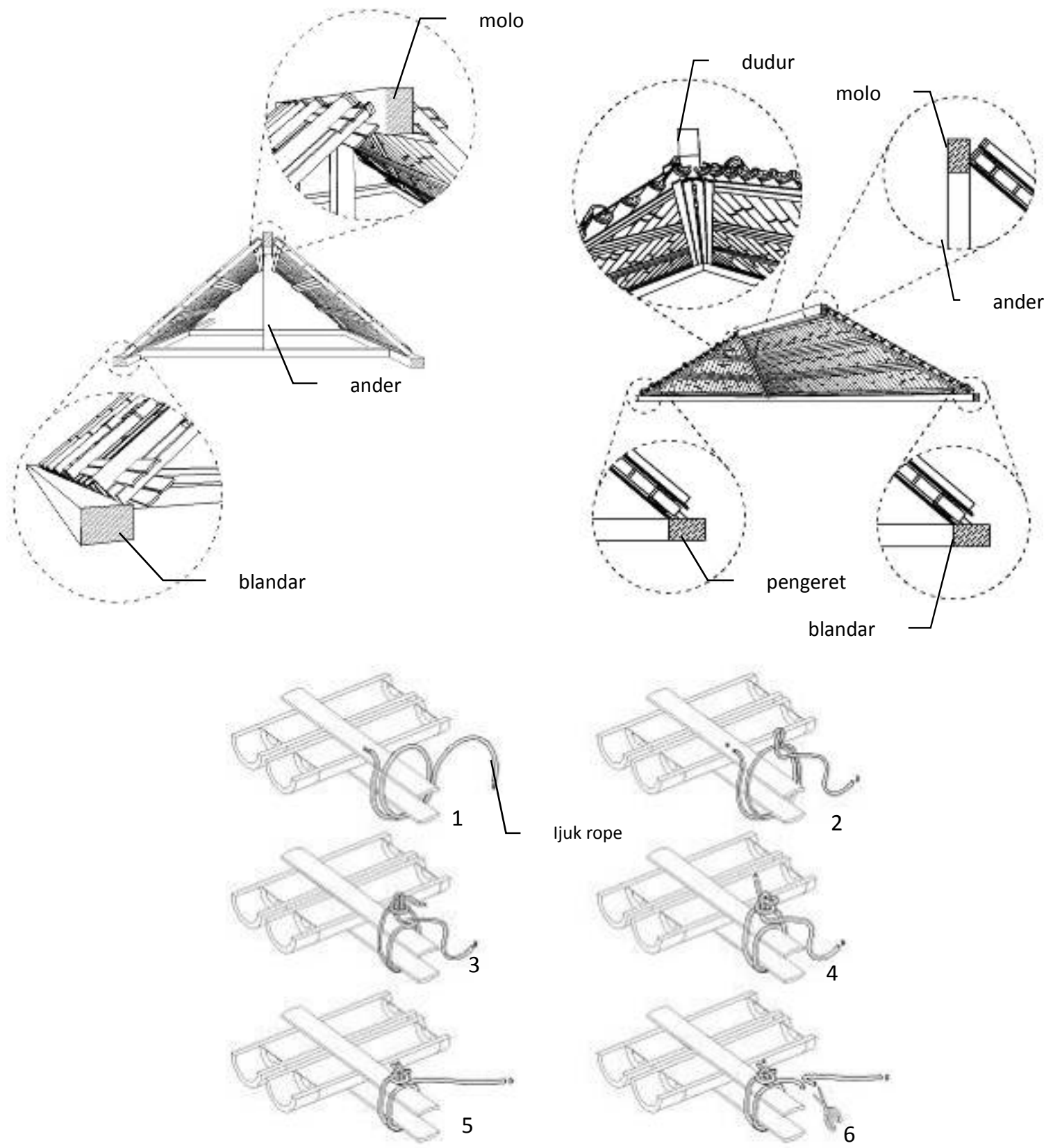

Figure 3. Empyak Assemblies Detail (Source: author) 
Each component is arranged with a tied system using traditional rope called duk or ijuk. This material is reliable and very simple to be applied. The principal of ijuk knot is by pulling a pair of gapit, so that will clamp usuk from both sides because the bamboo is an elastic material. It can return to its original shape when stress is removed (Schodek,1998). So, when two opposing gapit tied up, it will react to tighten the clamps. There is a specific looping technique to use ijuk rope. The benefit of this method is it safer to tied it up a bare hand. ljuk had a sharp tip and stiff properties that can hurt human skin.

All of the empyak panels must be placed on the structure frame (rong-rongan). In kampong houses, the empyak panel must rely on blandar beam (cc1), In limasan type, trapezoidal panel relies on blandar, and triangle panel will rely on pengeret beam. At the roof peak, all panel rely on molo beam. At the bottom connection, the panel was detained with wooden anchors, so that the panel will not slip down. At the upper connection, the panel was tied to molo with the bamboo rope called plilit. The diagonal side of the panels (limasan house) will be hung on the serving beam.

On the tip of the roof, there is the additional element which is the extension of the gendong, which to support ridge cover at the top of the roof, The upper rod tip of this element will meet each other from the opposite panel.

\section{Empyak as a Part of The Structure System}

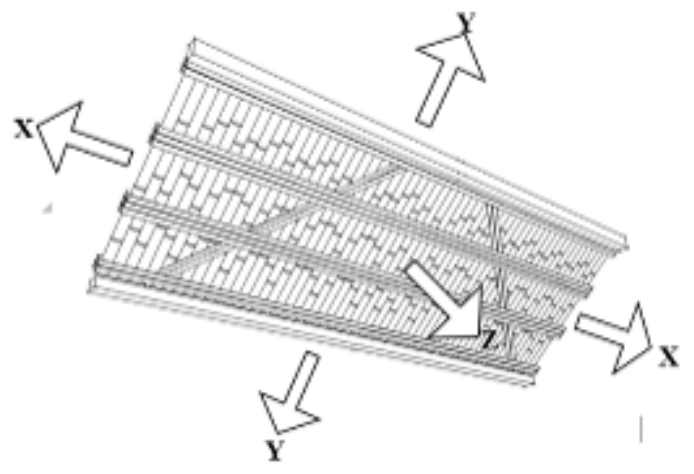

Figure 3. Force Direction Analysis (Source: author)

The element of the building would be structuralvalue if it became a part of loading transmission system of the building. One parameter of structure is the stability of the shape. Several forces can affect the stability of the building. This paper will examine the effect of tension force, compression force, bending force, shear force, and torsion force to the empyak construction. The fo7hiprce that possibly works on empyak construction from $x$-axis, $y$-axis, $z$-axis directions needs to be examined to understand the effect of force on construction stability.

\subsection{Compression Force Analysis}

When compression force occur to an object, it will tend to shorten (Schierle, 2006). Compression force that works in the direction of $y$-axis is detained by usuk. The close arrangement of usuk will keep the stability of empyak. The installation angle of empyak can potentially cause empyak pushed out from the blandar beam. There is some wooden anchor to lock the downside of the panel and detain the movement.

The compression force of $\mathrm{x}$-axis direction is perpendicular with usuk rods. Half-circle usuk unstable to withstand the force from the side. There is two possibility that happens to the material of usuk. First, the usuk will be distorted because of pressure. In this case, the tightness of gapit clamps will help usuk still on its position. Second, if the compression force is strong enough, it could crack the material of usuk. So the knots of bamboo play its part to strengthen the bamboo material from cracking.

The compression force that perpendicular to the empyak surface (z-axis) do not affect the stability of empyak significantly. It is because there is loads from above but no counter loads from below. So the compression forces will not work in this direction. 


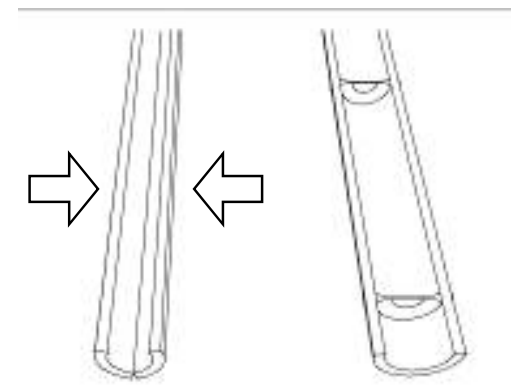

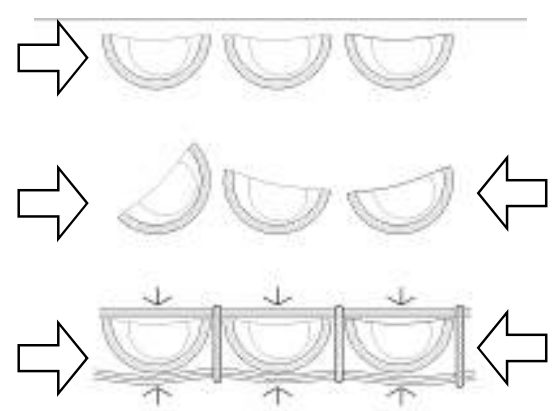

Figure 4. Usuk Construction Failure (Source: author)

\subsection{Tension Force Analysis}

When tension force occurs to an object, it tends to elongate (Schierle, 2006). The empyak ability to resist the tension force of $\mathrm{x}$ axis direction is fragile because all the connection of each element only use rope. Empyak is not a homogeneous panel. If empyak pulled from the $\mathrm{x}$-axis, the arrangement of usuk could be stretchable. In reality, this potential treatment happens when the transporting or installation process.

In the y-axis direction, the tension force tends to disrupt the arrangement of empyak to the tension strength of bamboo quite high (Widyowijatnoko, 2008), it does not affect the stability of the panel. It because the panel construction makes every rod to withstand tensile force individually. In reality, the level of tension from these direction almost zero when it already installed on the primary structure.

The tension force that perpendicular with the surface of empyak (z-axis) do not affect the stability of empyak significantly because there is tension on the surface of the empyak. So the tension forces do not work in this direction.

\subsection{Bending Force Analysis}

When bending force occurs to an object, it will tend to elongate on one side and shortens on the other side (Schierle, 2006). On the $y$-axis direction, it is difficult to bend the panel because of the width of the panel. The higher the vertical cross-section of the beam, the greater the ability to withstand bending forces. (Baden-Powell, 2001).

Other than that, if we try to put force on the $y$-axis of the panel and parallel to the direction of usuk, it will slide the usuk from the original position. The installation of empyak must prevent the movement of usuk by putting the downside of the empyak panel on the top side of blandar or pengeret. So that, every usuk will step on the plane surface of the beam.

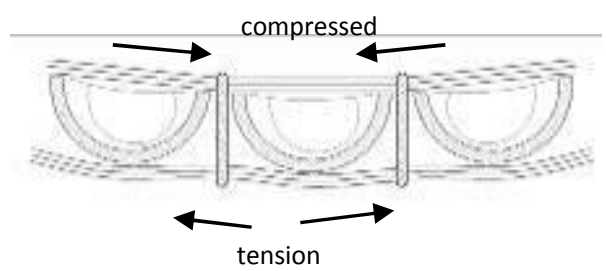

Figure 5. Effect of Bending Force to Empyak (Source: author)

As an individual material, the force from the side will bends usuk, but as a panel it hard to bend the panel in the $x$-axis direction. The essential elements to resist bending force front $x$-axis are the usuk and the strength of the tie. The tight assembling of usuk could reduce usuk to buckle. The other element is gendong. With circular crosssection, gendong is stronger to resist bending forces compared to half-circular cross section usuk.

There are two-ways of bending force on this Z-axis direction, transverse and longitudinal to the direction of usuk. Elements that play its part to resist transversal buckling is usuk and gendong. Elements that play its part to resist longitudinal buckling is gapit. Gapit at the front side and the back side of empyak will work together to resist buckling. When the front gapit withheld tension force, the backside gapit will withhold compression forces. And the other hand, when the backside gapit withstand tension force, the frontside gapit will withstand compression forces. 


\subsection{Shear Force Analysis}

When shear force occurs to an object, it will slide the adjacent part of the element (Schierle, 2006). The arrangement of usuk without rigid locking systems will the very easy to slide. The effect of sliding only reduced by the tightness of the ijuk. When the force from the direction of $x$-axis and $y$-axis occur, the tie system will take part to stabilize the construction. The stronger the tie, the

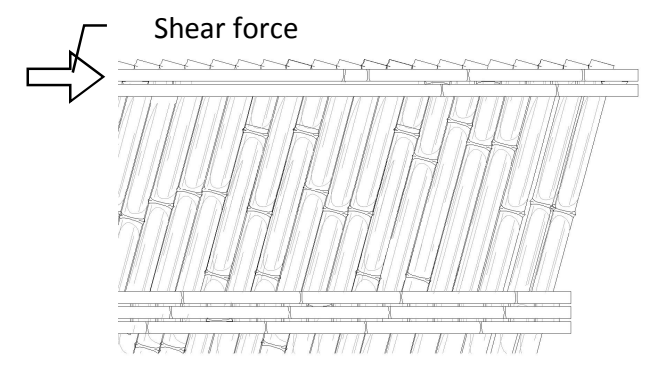

stronger the friction between usuk and gapit. The other elements that will help the panel to resist shear force are gapit sidang. Gapit sidang serves as the diagonal system to obtain stable forms (Schodek, 1995).

The effect of shear force on the direction of z-axis barely not seen because of the thick of panel is too small compared to the length and the width of empyak so that it will reduce moment force.

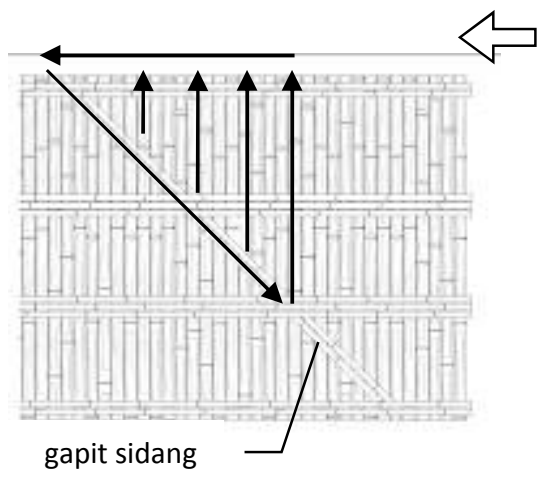

Figure 6. Effect of Shear Force to Empyak (left) and Resistant Mechanism to Shear Force (right) (Source: author)

\subsection{Torsion Force Analysis}

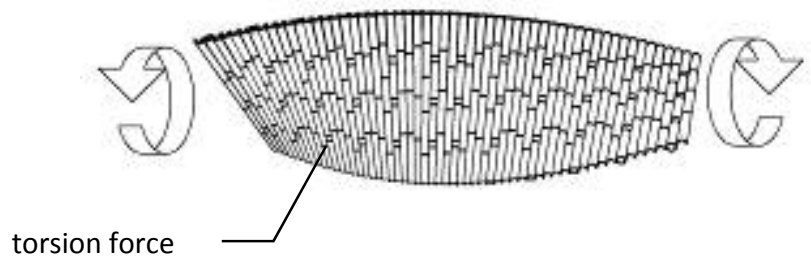

Figure 7. The Effect of Torsion Force to Empyak (Source: author)

The torsion force will twist the panel (Schierle, 2006). Gapit and gapit sidang both resist the torsion force from the $\mathrm{x}$-axis and the $y$-axis direction. The construction of empyak so prone to maintain its stability form torsion forces. The thickness of the empyak panel is too small compared to its length and width. So it makes empyak very easy to twist with small effort. So, traditionally, to lift up the empyak panel, many people needed, not just because of the weight, but the more people will maintain the stability of its shape during the lifting process. After it is placed in the main structure, the stability of the panel will depend on the structure stability.

\subsection{Joint}

Empyak is not united with stiffed joints to the main structure. The bottom connection is composed of a wooden peg that is inserted into the hole part of the bamboo. The upper connection is tied with the bamboo rope (plilit). Both kinds of the connections give the advantages to reduce the vibration energy, like the earth quake. Because, the stiffed joint will transmit the tremor to other building elements (Maer, 2008).

According to the explanation above, we can identify the function of each elements to resist external forces from many directions, and maintain the stability of the structure, as in the table below. 


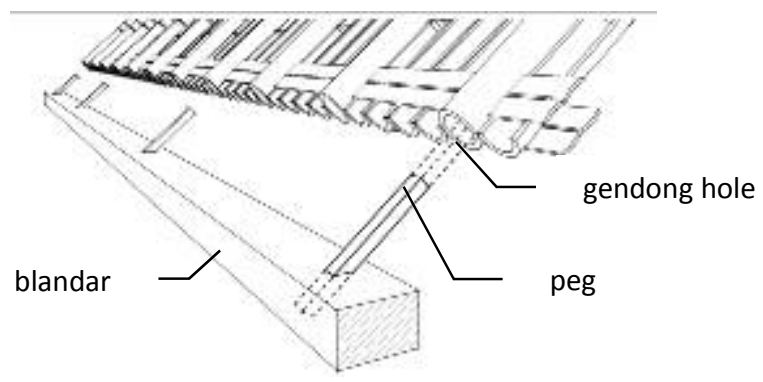

Figure 8. Detail of Bottom Connection of Empyak (Source: author)

\section{CONCLUSION}

Tabel 1. The Role of Empyak Elements to Resistant Forces

\begin{tabular}{|c|c|c|c|c|c|c|c|c|c|c|}
\hline \multicolumn{2}{|c|}{$\begin{array}{l}\text { U } \\
\text { 员 } \\
\mathbb{L}\end{array}$} & צ & 虽 & $\frac{\mathfrak{c}}{\frac{\pi}{\alpha}}$ & 比杂 & 꽁이 & 蛋采 & 号 & 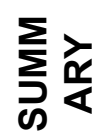 & $\frac{1}{\leftarrow}$ \\
\hline \multirow{3}{*}{$\begin{array}{l}\text { COMPRES } \\
\text { SION }\end{array}$} & $\mathrm{X}$-axis & $\sqrt{ }$ & $\sqrt{ }$ & $\sqrt{ }$ & - & - & - & - & 3 & \\
\hline & Y-axis & $\sqrt{ }$ & $\sqrt{ }$ & - & - & $\sqrt{ }$ & $\sqrt{ }$ & - & 4 & 8 \\
\hline & Z-axis & - & $\sqrt{ }$ & - & - & - & - & - & 1 & \\
\hline \multirow{3}{*}{ TENSION } & $\mathrm{X}$-axis & - & - & $\sqrt{ }$ & - & - & - & - & 1 & \\
\hline & Y-axis & $\sqrt{ }$ & $\sqrt{ }$ & - & - & $\sqrt{ }$ & - & - & 3 & 5 \\
\hline & Z-axis & - & - & - & - & - & - & $\sqrt{ }$ & 1 & \\
\hline \multirow{3}{*}{ BENDING } & $\mathrm{X}$-axis & $\sqrt{ }$ & $\sqrt{ }$ & $\sqrt{ }$ & $\sqrt{ }$ & - & - & $\sqrt{ }$ & 5 & \\
\hline & $\mathrm{Y}$-axis & - & $\sqrt{ }$ & - & $\sqrt{ }$ & $\sqrt{ }$ & $\sqrt{ }$ & $\sqrt{ }$ & 5 & 15 \\
\hline & Z-axis & - & $\sqrt{ }$ & $\sqrt{ }$ & - & $\sqrt{ }$ & $\sqrt{ }$ & $\sqrt{ }$ & 5 & \\
\hline \multirow{3}{*}{ SHEAR } & $\mathrm{X}$-axis & - & $\sqrt{ }$ & $\sqrt{ }$ & $\sqrt{ }$ & - & - & $\sqrt{ }$ & 4 & \\
\hline & Y-axis & $\sqrt{ }$ & $\sqrt{ }$ & $\sqrt{ }$ & $\sqrt{ }$ & $\sqrt{ }$ & $\sqrt{ }$ & $\sqrt{ }$ & 7 & 14 \\
\hline & Z-axis & - & $\sqrt{ }$ & - & $\sqrt{ }$ & - & - & $\sqrt{ }$ & 3 & \\
\hline \multirow{3}{*}{ TORSION } & $\mathrm{X}$-axis & - & - & $\sqrt{ }$ & - & $\sqrt{ }$ & $\sqrt{ }$ & $\sqrt{ }$ & 4 & \\
\hline & Y-axis & $\sqrt{ }$ & - & $\sqrt{ }$ & - & $\sqrt{ }$ & $\sqrt{ }$ & $\sqrt{ }$ & 5 & 9 \\
\hline & Z-axis & - & - & - & - & - & - & - & 0 & \\
\hline \multicolumn{2}{|c|}{ TOTAL } & 6 & 10 & 8 & 5 & 7 & 6 & 9 & & \\
\hline
\end{tabular}

The empyak structure has diagonal elements (gapit sidang) which serves to maintain the stability of the shape from the influence of lateral forces. Empyak also serves to maintain the stability of the roof frame from both transverse and longitudinal directional force. Although the main frame of the building does not have diagonal bracing, such as truss, the empyak can replace the function of bracing to achieve structure stability. Most influential forces to empyak stability are bending and shear force. In the other hand, the least influential force to empyak stability is tension force. Elements that were most responsible for maintaining the stability of empyak are gendong, gapit, and ijuk. The joint between empyak and the main frame is not a permanent and rigid so that it can serve as a vibration damper.

\section{ACKNOWLEDGMENT}

The authors would like to thank the Ministry of Research, Technology and Higher Education through grant scheme of the Overseas Joint Collaboration Research and International Publication (663/M/KP/XII/2015 and $041 / \mathrm{HB}-\mathrm{LT} / \mathrm{IV} / 2017$ ) to support this research.

This research was supported by Drs. M. Syakir Ali, M.Si. We thank our colleagues Tesa Arsitektur Volume 15| Nomor 2 | 2017 
from Universitas Islam Indonesia and Universitas Gajah Mada who provided insight and expertise that greatly assisted the research, although they may not agree with all of the interpretations/conclusions of this paper.

We thank Dr. Ir. Arya Ronald for assistance with writing technique, and for comments that greatly improved the manuscript.

We would also like to show our gratitude to the Universitas Gajah Mada for sharing their pearls of wisdom with us during this research, and we thank 3 "anonymous" reviewers for their so-called insights. We are also immensely grateful to Aspin Latif, ST., M.Sc., Irwan Dharmawan, ST. M.Sc for their comments on an earlier version of the manuscript. Although any errors are our own and should not tarnish the reputations of these esteemed persons.

\section{REFERENCES}

Baden-Powell, Charlotte. (2001). Architect's pocketbook/Charlotte Baden-Powell [2nd ed.]. p. cm. Includes index ISBN 0 75064764 7. Burlington: Esevier

Cowan, Henry J. (1971). Architectural Structures: An Introduction to Structural Mechanics. American Elsevier: Newyork.

Crane, Theodore. (1947). Architectural Construction. John Wiley \&Sons: New York.

Frick, Heinz. (1997). Pola Struktural dan Teknik Bangunan di Indonesia. Kanisius: Yogyakarta

Frick, Heinz. (2004). IImu Konstruksi Bangunan Kayu. Kanisius: Yogyakarta

Ghavami, K. (2008). Bamboo: Low cost and energy saving construction materials. Modern Bamboo Structures - Xiao et al. (eds) (c) 2008 Taylor \& Francis Group, London, ISBN 978-0-415-47597-6
Hamzuri. Rumah Tradisiona Jawa. Proyek Pengembangan Permuseuman DKI Jakarta. Seri Rumah. Departemen Pendidikan dan Kebudayaan.

Ismunandar. (2007). Joglo : Arsitektur Rumah Tradisional Jawa. Effhar: Semarang

Jayanetti, D.L. \& Follett, P.R. (2008). 23 Bamboo in construction. Modern Bamboo Structures - Xiao et al. (eds) ( 2008 Taylor \& Francis Group, London, ISBN 978-0-415-47597-6

Maer, Bisatya W. (2008). Respon Pendopo Joglo Yogyakarta Terhadap Getaran Gempa Bumi. DIMENSI TEKNIK ARSITEKTUR Vol. 36, No. 1, Juli 2008: $1-9$

Marshall, W. T. (1969). Structures. London: Pitman

Prihatmaji, Yulianto P. (2007). Perilaku Rumah Tradisional Jawa "joglo" Terhadap Gempa. DIMENSI TEKNIK ARSITEKTUR Vol. 35, No. 1, Juli 2007: $1-12$

Ravi Mullapudi, T., Ayoub, Ashraf. (2010). Modeling of The Seismic Behavior of Shear-critical Reinforced Concrete Columns. Journal Engineering Structures Vol. 32, Issue 11, Pages : 3601-3615

Schodek, Daniel L. (1997). Structure. Bandung: Refika Aditama.

Schierle, G.G. (2006). Architectural Structure Excerpts. Los Angeles: University of Southern California.

Soeroto, Myrtha. (2003). Dari Arsitektur Tradisional Menuju Arsitektur Indonesia. Galia Indonesia: Jakarta

Waterson, Roxana. (1998). The Architecture of South -East Asia through Travelers' Eyes. Oxford University Press: New York.

Widyowijatnoko, A. Prefabricated low-cost housing using bamboo reinforcement and appropriate technology. Modern Bamboo Structures - Xiao et al. (eds) (C) 2008 Taylor \& Francis Group, London, ISBN 978-0-415-47597-6 